\title{
KOMUNIKASI DALAM KEGIATAN PUBLIC RELATIONS
}

\author{
Rumsari Hadi Sumarto \\ Asmi Desanta \\ hrumsari@yahoo.com
}

\begin{abstract}
Organizations in maintaining the sustainability of life requires communication. Good established communication will affect the harmonious and harmony relations between the organization and its publics. A positive image is represented if there is a harmonious interaction between an organization and its publics. Imaging of an organization is usually attached to public relations. Imaging can be awakened/built if there is a harmonious and pleasant communication between an organization and its publics. To support public relations activities, organization requires communication to be able to interact with the public in two-way communication. A PR practitioner should be able to make other people understand the message delivered so as to create mutual symbiosis between the two parties. Thus, the impression captured by the public is a positive impression of the organization. Public relations also allows feed back to the public so that the public can freely response the message from the organization and express what they want and what they complaint. The public response will be followed up so that the public will be satisfied on what the organization done to the public. Public relations is also constantly evaluating so that public opinion can be well controlled. Thus, public relations is an activity which essentially directs the organization to gain public recognition. Further public relations stride motion seeking to form public opinion that benefit the organization so that a positive image of the public will be given to an organization.
\end{abstract}

\begin{abstract}
Abstrak
Organisasi akan tetap langgeng saat terbangun komunikasi yang baik. Komunikasi yang baik akan mempengaruhi hubungan yang harmonis dan selaras antara organisasi dan publiknya. Sebuah citra positif terbangun jika ada interaksi yang harmonis antara organisasi dan publiknya. Untuk mendukung kegiatan public relations, organisasi membutuhkan komunikasi dua arah. Seorang praktisi PR harus mampu membuat orang lain memahami pesan yang disampaikan sehingga tercipta simbiosis antara kedua belah pihak. Dengan demikian, kesan yang ditangkap oleh masyarakat adalah kesan positif dari organisasi. PR juga memungkinkan umpan balik kepada publik sehingga masyarakat dapat dengan bebas mendapat pesan dari organisasi dan mengekspresikan apa yang mereka inginkan dan apa yang mereka keluhan. PR juga perlu terus mengevaluasi sehingga opini publik dapat dikontrol dengan baik. Dengan demikian, $P R$ adalah kegiatan yang pada dasarnya mengarahkan organisasi untuk memperoleh pengakuan publik. PR berusaha untuk membentuk opini publik yang menguntungkan organisasi sehingga citra positif terbangun dengan sendirinya.
\end{abstract}

Keywords: Communication, Public Relations, Organizational Image 


\section{PENDAHULUAN}

Komunikasi memegang peranan penting dalam kehidupan manusia. Manusia tidak dapat hidup sendiri sehingga membutuhkan interaksi dengan pihak lain. Jembatan interaksi tersebut dilakukan melalui komunikasi. Pada saaat berkomunikasi, pihak yang menyampaikan pesan atau komunikator berusaha menyampaikan pesan sedemikian rupa sehingga pesan yang disampaikan dapat dipahami oleh penerima pesan atau komunikan dan kemudian komunikan akan memberikan feed back atau umpan balik atas pesan yang disampaikan tersebut. Nampaknya sederhana proses komunikasi tersebut berlangsung. Namun, dalam kenyataannya tidaklah demikian.

Apabila komunikator kurang mahir dalam menyampaikan pesan, maka komunikan akan gagal menangkap pesan yang disampaikan dan dampaknya dapat terjadi miss communication. Bahkan apabila komunikator dalam menyampaikan pesan tidak memperhatikan kesantunan dalam berbahasa, maka bisa terjadi komunikan akan memberikan reaksi atau tanggapan negatif karena komunikator tidak menggunakan etika dalam berkomunikasi.

Hal ini sering terjadi dalam kehidupan sehari-hari tidak terkecuali pada suatu organisasi. Kegagalan organisasi dalam menyampaikan pesan terutama kepada pihak eksternal organisasi akan memberi stigma negatif tentang organisasi tersebut. Kesalahan dalam berkomunikasi yang terjadi pada suatu organisasi dapat menjadi 'stempel' buruk yang terpatri pada masyarakat walaupun organisasi sudah meluruskan informasi yang berkembang.

Dampaknya adalah timbulnya citra negatif dari organisasi tersebut. Publik akan membentuk opini yang kurang menguntungkan apabila organisasi kurang mampu berkomunikasi dengan publiknya. Oleh karena itu, para pegawai harus benarbenar dapat memahami publik baik cara berpikir dan cara bersikap sebelum informasi disampaikan kepada khalayak umum. Dengan demikian, publik akan bersikap positif terhadap apa yang disampaikan organisasi kepada publiknya. Komunikasi yang disampaikan juga dilakukan dengan mengedepankan etika sehingga dapat meminimalisir kesalahan persepsi dalam berkomunikasi.

Pencitraan suatu organisasi biasanya melekat dengan public relations. Pencitraan dapat terbangun bila ada komunikasi yang harmonis dan menyenangkan antara organisasi dengan publiknya. Menurut Kasali (Mukarom dan Muhibudin Wijaya Laksana 2015: 19) public relations merupakan pendekatan yang sangat strategis dengan menggunakan konsep-konsep komunikasi.

Public relations mencoba membuka kran komunikasi yang menyenangkan dengan publiknya. Komunikasi yang dijalin akan berdampak pada hubungan yang serasi dan selaras antara organisasi dengan publiknya.Sebagai dampaknya adalah opini publik yang positif akan terbangun dan akan menguntungkan organisasi untuk keberlangsungan hidup suatu organisasi.

\section{HASIL DAN PEMBAHASAN}

\section{Pengertian dan Fungsi Komunikasi}

Dalam kehidupan seseorang di tengah masyarakat, komunikasi menjadi sarana untuk menjalin hubungan sehingga seseorang tidak merasa terisolasi di tengah kehidupan bersama tersebut. Dengan adanya komunikasi, seseorang dapat mengekspresikan perasaannya atau keinginannnya dan pihak lain dapat memberikan umpan balik atas pesan yang disampaikan.

Menurut Hubeis, dkk (2012: 5) komunikasi adalah proses penyampaian suatu pesan oleh seseorang kepada orang lain untuk memberitahu atau untuk mengubah sikap, pendapat, atau perilaku baik langsung (secara lisan) maupun tidak langsung (media), proses penyampaian arti terhadap gagasan atau ide yang disampaikan baik sengaja maupun tidak sengaja.

Sedang menurut Hovaland (Wiryanto 2002: 6), komunikasi merupakan proses di mana individu mentransmisikan stimulus 
untuk mengubah perilaku individu lain. Menurut Suranto (2005: 16) komunikasi adalah suatu proses pengiriman simbolsimbol yang mengandung arti dari seorang komunikator kepada komunikan dengan tujuan tertentu.Sedang menurut Ruslan (1997: 29), komunikasi secara efektif dan strategis pada prinsipnya adalah bagaimana mengubah sikap, mengubah opini, dan mengubah perilaku.

Dengan demikian, komunikasi merupakan proses penyampaian pesan atau gagasan baik secara langsung maupun tidak langsung. Dampak dari pesan tersebut dapat mengubah sikap seseorang sehingga selaras dengan apa yang menjadi ekspetasi penyampai pesan. Komunikasi juga dapat mengubah opini yang selama ini terbentuk terlebih opini yang negatif. Opini negatifbisa menjadi positif setelah berlangsung komunikasi yang intens antara penyampai pesan dan penerima pesan.

Menurut Cangara (2007: 11-12). Beberapa alasan yang mendorong perlunya komunikasi adalah:Komunikasi yang baik dengan orang lain akan membantu seseorang mempermudah memperoleh rezeki, sahabat dan pelanggan; Semakin banyak orang yang tidak mengenal etika dalam berkomunikasi; Bisamenjadipekerja komunikasiyang trampil dan profesional dalam melaksanakan tugas yang diembannya; Perkembangan teknologi komunikasi yang begitu cepat memaksa orang harus mendapat pengetahuan dan ketrampilan baru terutama dalam bidang komputer.

Tidak dapat dipungkiri bahwa manusia sebagai mahluk sosial tidak dapat hidup sendiri. Manusia membutuhkan orang lain dalam menjalani kehidupannya sehingga manusia tersebut dapat melangsungkan kehidupannya dengan memperoleh rezeki sebagai dampak dari interaksi yang dilakukan dengan pihak lain, dapat memiliki sahabat sebagai tempat untuk menyampaikan perasaannya. Dengan demikian, manusia membutuhkan orang lain untuk menjalani kehidupannya termasuk dalam mencari nafkah ataupun berbagi perasaaan sehingga mampu meringankan beban hidup baik secara material maupun psikisnya.

Perlunya mempelajari komunikasi juga erat dengan fenomena interaksi yang berkembang saat ini. Era global saat ini telah mengubah tatanan interaksi yang ada sehingga etika dalam berkomunikasi dapat diasumsikan menjadi semakin pudar. Seseorang dapat menjadi tidak peduli dengan lingkungannya dan sulit untuk berkomunikasi secara santun terutama dengan orang yang lebih tinggi usianya. Hal ini dapat dirasakan untuk era saat ini terutama pada generasi muda yang semakin canggih dalam mengakses teknologi informasi tetapi mengalami kendala dalam berinteraksi dengan orang lain termasuk di dunia kerja.

Kemudahan dalam mengakses informasi menyebabkan seseorang sangat bergantung dengan teknologi informasi dan menjadikan dirinya semakin individual karena teknologi dianggap dapat membantu menyelesaikan pekerjaan mereka. Sementara itu, di sisi lain bila seseorang tetap menjalin komunikasi dengan pihak lain secara santun tanpa menafikan keberadaan teknologi informasi, makahal tersebutakan menjadikan seseorang semakin diakui keberadaannya sehingga terlihat profesional dalam melakukan pekerjaannnya.Sekalipun orang tersebut beradu argumentasi dengan orang lain, tetapi orang tersebut mampu menyampaikan pendapatnya tanpa menyudutkan pihak lain. Orang tersebut sangat paham bagaimana berkomunikasi dengan orang lain, baik dengan atasannya, dengan sesama rekan kerja, bahkan dengan kliennya. Walaupun demikian, tidak dapat dipungkiri dengan adanya kemajuan teknologi, arus komunikasi menjadi semakin terbuka dan mengakibatkan setiap orang atau pegawai harus mampu berada pada situasi global termasuk bagaimana menjalin interaksi secara terbuka dengan bermacam-macam media komunikasi yang ditawarkan saat ini.

Adapun fungsi komunikasi menurut Goran Hedebro (Cangara 2007: 63) yaitu:Menciptakan iklim perubahan dengan memperkenalkan nilai-nilai baru untuk mengubah sikap dan perilaku ke arah modernisasi;Mengajarkanketerampilanbaru; 
Sebagai pelipat ganda ilmu pengetahuan; Merupakanefisiensitenagadanbiayaterhadap mobilitas seseorang; Meningkatkan aspirasi seseorang; Menumbuhkan partisipasi dalam pengambilan keputusan; Membantu orang menemukan nilai baru dan keharmonisan dalam situasi tertentu; Mempertinggi rasa kebangsaan; Mengubah struktur kekuasaan dalam suatu masyarakat; Menjadi sarana untuk membantu pelaksanaan program pembangunan; Mendukung pembangunan ekonomi, sosial dan politik suatu bangsa.

Dengan adanya komunikasi, akan terjadi iklim perubahan dengan masuknya nilai-nilai baru yang dapat mengubah sikap ke arah modernisasi. Hal ini memang tidak dapat dipungkiri bahwa aura modernisasi telah mengisi segala sisi kehidupan. Seseorang memang perlu mengakses informasi modern yang dapat menjadikan dirinya tidak terlibas di era modern saat ini. Namun demikian, orang tersebut juga diharapkan dapat memilah-milah informasi yang bermanfaat bagi dirinya yang dapat memperkaya wawasannya. Hal ini akan menjadikan seseorang tidak kaku dan tidak tampak terkesan 'kuno' saat berinteraksi dengan orang lain di dunia modern.

Komunikasi juga dapat berkontribusi pada efisiensi tenaga dan biaya mobilitas di mana seseorang tidak perlu beranjak ke suatu tempat yang dituju untuk berkomunikasi dengan pihak lain karena saat ini fasilitas komunikasi canggih dengan berbagai fitur dapat membantu seseorang untuk berkomunikasi dengan cepatbahkan mampu bertatap muka dengan bantuan teknologi informasi.Dengan komunikasi juga, seseorang dapat berkontribusi dalam pengambilan keputusan yang ada pada suatu organisasi. Dengan demikian keputusan yang diambil merupakan keputusanyang mewakili suara dari para personal organisasi.

Komunikasi juga mampu mengubah struktur kekuasan masyarakat dari yang otoriter menjadi lebih demokratis mengingat masyarakat yang ada saat ini merupakan masyarakat yang kritis dan canggih dalam mengakses teknologi informasi. Dengan demikian, suasana keterbukaan saatini antara penguasa dengan rakyatnya merupakan hal yang harus dilakukan. Dalam konteks suatu negara, komunikasi mampu menjadi sarana dalam membantu pelaksanaan program pembangunandengan pencurahan idekreatif dalam membangun suatu bangsa sehingga dapat membantu dalam pembangunan ekonomi. sosial dan politik suatu bangsa.

\section{Public Relations}

Komunikasi dalam realisasinya dapat terpapar dalam kegiatan public relations. Public relations sangat membutuhkan komunikasi untuk merealisasikan kegiatannya. Hubungan timbal balik antara organisasi dengan publiknya merupakan prinsip yang harus dijalankan. Menurut Effendy (2002: 23) hubungan masyarakat adalah komunikasi dua arah dengan publik secara timbal balik dalam rangka mendukung fungsi dan tujuan manajemen dengan meningkatkan pembinaan kerja sama dan pemenuhan kepentingan bersama.Lebih lanjut Mukarom dan Muhibudin Wijaya Laksana (2015: 20) mengatakan bahwa staf public relations dituntut mampu menjadikan orang-orang lain memahami suatu pesan, demi menjaga reputasi atau citra lembaga yang diwakilinya.

Dengan demikian, praktisi humas harus dapat membentuk nilai-nilai, pemahaman, sikap sampai perilaku dari publik agar sejalan dengan kebutuhan organisasi. Praktisi public relations dituntut mampu menggiring publiknya sehingga mampu mengarahkan perhatian publik terhadap pesanyang disampaikan. Tidak hanya sekedar mengarahkan perhatian tetapi pesan yang tersampaikan tersebut membawa dampak publik melangkah lebih jauh untuk berjalan selaras dengan tujuan organisasi dengan misi tetap pada pemenuhan kepentingan bersama.

Menurut Rex Harlow,public relations adalah fungsi manajemen khas yang mendukung pembinaan dan membangun upaya saling menguntungkan melalui komunikasi, pengertian, penerimaan, dan kerja sama yang baik antara organisasi 
dengan publiknya (Ruslan 1997: 7).Public relations merupakan komunikasi dua arah secara timbal balik sehingga dalam penerapannya seorang praktisi PR harus mampu menjadikan orang lain memahami pesan yang disampaikan sehingga tercipta simbiose mutualisme di antara dua belah pihak. Hal ini dilakukan untuk pembentukan citra organisasi sehingga kesan yang ditangkap publik adalah kesan yang positif tentang suatu organisasi.

Adapun ciri dari hubungan masyarakat menurut Effendy (2002: 24) adalah:Humas adalah kegiatan komunikasi dalam suatu organisasi yang berlangsung dua arah secara timbal balik; Humas merupakan penunjang tercapainya tujuan yang ditetapkan manajemen dalam suatu organisasi; Publik yang menjadi sasaran public relations adalah publik ekstern dan publik intern; Operasionalisasi humas adalah membina hubugan yang harmonis antara organisasi dengan publik dan mencegah terjadinya rintangan psikologis baik yang ditimbulkan dari pihak organisasi maupun dari pihak publiknya.

Pada dasarnya kegiatan public relations dilakukan untuk menunjang kegiatan manajemen dalam mencapai tujuan organisasi dengan membina hubungan yang harmonis dengan publiknya baik publik internal maupun publik eksternal. Oleh karena itu, organisasi selalu mengedepankan komunikasi dua arah dalam memenuhi ekspetasi publik sehingga arus komunikasi menjadi selaras di antara organisasi dan publiknya. Publik akan memperoleh informasi yang berimbang dengan model komunikasi dua arah tersebut. Iklim keterbukaan yang dibangun oleh organisasi akan menembus rintangan psikologis dan kekakuan dalam berkomunikasi di antara organisasi dan publiknya.

Mukarom dan Muhibudin Wijaya Laksana (2015: 40) mengatakanbahwa public relations berkaitan dengan bentuk komunikasi yang berlaku untuk semua organisasi, Artinya public relations jauh lebih luas dibanding dengan pemasaran dan periklanan atau propaganda yang lebih
awal.Mukarom dan Muhibudin Wijaya Laksana (2015: 42) menambahkan bahwa humas merupakan salah satu elemen yang menentukan kelangsungan organisasi secara positif. Arti penting humas sebagai sumber informasi terpercaya semakin terasa di era global dan banjir informasi seperti saat ini.

Organisasi dalam menjalankan operasionalnya pasti membutuhkan komunikasi. Keberlanjutan organisasi salah satunya ditentukan bagaimana organisasi mampu berkomunikasi dengan publiknya. Public relations diharapkan menjadi sumber informasi yang dapat dipercaya publik sehingga kesan positif akan terepresentasi dengan baik dari publiknya. Di tengah arus informasi yang begitu pesat dan mengglobal saat ini menjadikan organisasi harus gencar berkomunikasi misalnya dengan meluruskan berita 'miring' tentang organisasinya atau pun gencar mempublikasikan organisasinya di tengah persaingan yang tidak terbendung lagi. Hal tersebut akan memberi dampak organisasi semakin dikenal publik dan menambah kepercayaan publik terhadap suatu organisasi.

Menurut Melvin Sharpe (Soemirat dan Elvinaro Ardianto 2012: 14-15) ada lima prinsip proses komunikasi dalam hubungan jangka panjang antara perusahaan dengan publiknyayaitu:Komunikasi yang jujur untuk memperoleh kredibilitas; Keterbukaan dan konsistensi terhadap tindakan dan kepercayaan; Tindakan yang jujur untuk mendapatkan hubungan timbal balik dan goodwill (kemauan baik); Komunikasi dua arah dilakukan secara kontinyu untuk mencegah alienasi (pengucilan) dan membangun hubungan; Evaluasi penelitian dan lingkungan untuk menentukan tindakan dan penyesuaian yang diperlukan bagi hubungan sosial yang harmonis.

Walaupun organisasi giat untuk melakukan komunikasi dengan publik terutama publik eksternal, pesan yang disampaikan setidaknya mampu membuat publik yakin atas informasi tersebut dan diharapkan publik memberi respon positif atas pesan yang disampaikan organisasi. Keterbukaan dan konsistensi atas pesan 
yang disampaikan sangat mendukung dalam memperoleh kepercayaan publik.Oleh karena itu, sangat penting untuk melakukan komunikasi dua arah dengan membuka kran feedback dari publik.

Sepanjang organisasi mampu menjelaskan kepada publik tentang keberadaan organisasi baik pada saat berjalan baik maupun sedang dalam keadaan genting, makapublikakan tetap menaruh kepercayaan terhadap organisasi. Evaluasi juga penting dilakukan untuk memperoleh gambaran tentang penerimaan publik terhadap suatu organsisasi sehingga keberadaan organisasi tetap diperhitungkan oleh publik bahkan mendapat porsi atensi yang lebih dari pada organisasi lainnya.Dengandemikian, penting untuk membangun hubungan yan harmonis dengan publiknya sehingga publik dapat mengakui keberadaan suatu organisasi.

\section{Aplikasi Komunikasi dalam Public Relations}

Komunikasi tidak bisa dilepaskan dari kegiatan public relations karena public relations membutuhkan komunikasi untuk menunjang kegiatannya. Menurut Ruslan (1997: 17), kegiatan public relations pada hakikatnya merupakan bagian dari teknik kegiatan berkomunikasi dengan ciri khas komunikasi dua arah antara lembaga atau organisasi yang diwakilinya dengan publik atau sebaliknya.Menurut Mukarom dan Muhibudin Wijaya Laksana (2015: 75) dalam kapasitasnya humas paling banyak menggunakan teori komunikasi sebagai dasar berpijaknya. Bahkan dapat dikatakan tidak ada teori komunikasi yang tidak dibutuhkan humas.

Public relations sangat membutuhkan komunikasi dalam melakukan kegiatannya. Ciri khas dari public relations adalah komunikasi dua arah. Public relations sangat peduli terhadap feed back yang disampaikan publik. Citra positif suatu organisasi tidak lepas dari bagaimana organisasi tersebut mampu berkomunikasi dengan baik kepada publiknya termasuk memberi respon yang baik kepada publik.
Menurut Mukarom dan Muhibudin Wijaya Laksana (2015: 91-101), teori komunikasi yang dibutuhkan dalam public relations adalah:Pertama, teori tanda. Pada prinsipnya pesan memiliki kedudukan yang sangat penting dalam komunikasi dan bagi praktisi humas penting karena humas merupakan kegiatan menyampaikan pesan. Pesan memiliki tiga unsur yaitu tanda, bahasa dan wacana.

Kedua, teori hubungan.Konteks ini berkaitan dengan kepentingan bagi praktisi humas dalam hal melakukan komunikasi interpersonal yaitu berbicara face to face dan memberi kesan yang baik dalam hubungannya dengan orang lain sehingga kesan positif yang diberikan orang terhadap praktisi humas akan mempengaruhi kesan orang tersebut terhadap organisasi.

Ketia, teori perubahan sikap. Teori memberi penjelasan terbentuknya sikap seseorang dan cara sikap itu dapat berubah melalui proses komunikasi dan sikap itu dapat mempengaruhi sikap atau tindak atau tingkah laku seseorang.

Keempat, teori penggunaan dan pemuasan. Teori ini mengasumsikan bahwa pengguna mempunyai pilihan untuk memuaskan kebutuhannya. Kelima, teori opini publik.Opini publik dapat diartikan sebagai pendapat masyarakat pada umumnya, integrasi pendapat secara over all atau keseluruhan.

Dalam kegiatannya, public relations diharapkan dapat menjalin hubungan yang serasidenganpubliknyabaikpublikbaikpublik internal maupun eksternal. Komunikasi face toface dapat memberikandampakyangcukup signifikan tentang kesan publik terhadap suatu organisasi. Publik dapat menilai sikap dan gaya bicara yang diekspresikan oleh personal organisasi sehingga publik dapat langsung memunculkan kesan saat berinteraksi dan kesan yang diharapkan adalah kesan yang positif. Namun demikian, tidak hanya kesan positif yang diberikan publik kepada organisasi tetapi publik akan melangkah lebih jauh dengan merubah sikap bahkan melakukan suatu tindakan yang menguntungkan organisasi. 
Publik pun tidak sebatas melakukan perubahan sikap atau melakukan sesuatu yang sesuai dengan ekspetasi organisasi, tetapi publik mendapatkan kepuasan atas apa yang disampaikan organisasi. Apabila ekspetasi publik dapat terpenuhi, maka publik akan meneruskan sinyal postif tersebut kepada pihak lain. Dengan adanya komunikasi berantai yang positif tersebut, maka akan terbangun opini publik yang menguntungkan organisasi.

Menurut Morrisan (Mukarom dan Muhibudin Wijaya Laksana 2015: 91-101), untuk mengimplementasikan strategi komunikasi, manajer PR atau humas harus berkomunikasi dan melakukan beberapa hal yaitu:satu, membingkai pesan yaitu strategi dalam memilih, menonjolkan dan menghubungkan fakta ke dalam bentuk pesan agar lebih bermakna, lebih menarik, lebih berarti atau lebih diingat.

Dua, memiliki nilai berita. Praktisi humas dituntut untuk lebih memahami dan mengetahui nilai pesan yang ingin disampaikannya ketika berkomunikasi. Terlebih jika pesan itu dikirimkan ke media massa.

Tiga, semiotika. Praktisi humas dituntut untuk mampu memilih dan mengirimkan kata-kata atau kebijakan kepada berbagai kalangan yang berbeda-beda sehingga katakata atau kebijakan itu dapat dipahami oleh penerima.

Empat, menggunakan simbol.Berbagai perusahaan baik yang bertujuan profit dan non profit menggunakan simbol untuk menciptakan citra atau persepsi di kalangan khalayak

Lima, stereotip. Komunikasi sering mengalamihambatandalampelaksanaannya. Hambatan muncul dalam berbagai bentuk mulai dari hambatan sosial, umur, bahasa, perbendaharaan kata, politik dan ekonomi.

Pesan yang disampaikan kepada publik sedapat mungkin didesain dengan format yang menarik dan lebih mudah diingat publik termasuk dalam hal mengemukakan fakta yang ada dalam suatu organisasi. Informasi berdasar fakta tersebut tidak hanya dipublikasikan secara sederhana tetapi memiliki nilai berita sehingga publik tertarik untuk memperhatikan pesan yang disampaikan terutama pesan yang dipublikasikan di media cetak maupun media elektronik.Publik akan tertarik untuk memfokuskan dirinya pada berita yang menarik dan berbeda dengan publikasi lainnya. Praktisi humas atau public relations dituntut untuk mampu merangkai kata demi kata secara lugas dan menarik.

Dalam menuangkan gagasan, tentunya praktisi public relations harus mampu melihat dengan siapa mereka berbicara. Bila komunikasi ditujukan kepada kaum muda tentunya bahasa yang disampaikan tidak terkesan kaku dan formal tetapi disampaikan dengan bahasa yang santai dan 'gaul'. Latar belakang pendidikan publik juga harus menjadi perhatian praktisi humas sehingga praktisi humas dapat menggunakan bahasa yang sesuai tingkat pendidikan publik. Simbol-simbol tertentu dapat dituangkan untuk lebih menyerap perhatian publik atas informasi yang disampaikan.

Tidak dapat terhindarkan juga bahwa komunikasi akan mengalami kendala bila stereotip muncul di tengah komunikasi yang berlangsung antara publik dan suatu organisasi. Misalnya stigma bahwa usia muda belum memiliki banyak pengalaman dibanding usia tua sering memunculkan kesan 'ragu' dari publik terhadap personal organisasi. Tentu saja hal ini harus diantisipasi sehingga personal organisasi tetap memiliki kredibilitas di hadapan publiknya walaupun usia personal organisasi lebih muda dari usia publiknya.

Menurut Hubeis (2012: 43) terdapat beberapa faktor agar komunikasi berlangsung efektif yang dinamakan dengan seven communication:Credibity, yaitu antara komunikator dan komunikan terdapat rasa saling percaya. Context, yaitu komunikasi dapat terjadi kalau situasi dan kondisi setempat tidak ada gangguan antara komunikator dengan komunikan, serta sarana atau media komunikasi yang saling berkaitan. Content, yaitu komunikator dapat menyampaikan pesan kepada komunikan di 
mana komunikan dapat memahami maksud komunikator sehingga komunikator merasa puas. Clarity, yaitu komunikator harus menyampaikan pesan secara jelas.

Continuty and Consistency, yaitu komunikasiberlangsungterusdanpesantidaksaling bertentangan. Capability of Audience, dalam hal ini komunikator harus memperhatikan kemampuan komunikan dalam menerima pesan agar tidak terjadi kesalahpahaman. Channels of Distribution, dalam hal ini komunikasi harus menggunakan media yang sudah biasa digunakan oleh umum, misalnya media cetak dan media elektronik.

Komunikasi akan berjalan dengan lancar dan menambah kepercayaan publik bila personal organisasi memiliki kredibilitas yang tinggi. Personal organisasi harus mampu meyakinkan publiknya tentang informasi yang disampaikan. Kredibilitas terpancar dari kemampuan berbicara dengan wawasan yang dimiliki juga didukung dengan komunikasi non verbal yang mampu meyakinkan publik. Komunikasi akan nyaman berjalan bila gangguan dapat diminimalisir terutama pada sarana yang digunakan untuk berkomunikasi. Bila sarana sangat mendukung arus komunikasi dan dilengkapi dengan kredibilitas dari personal organisasi, maka kepuasan publik akan terrepresentasi dengan baik.

Komunikasi juga harus berlangsung dengan baik dan lancar sehingga signifikan dengan kepuasan komunikator. Pesan yang disampaikan tidak membingungkan komunikandankomunikansendiri mendapat manfaat dari proses komunikasi yang terjadi. Dengan demikian, ada kepuasan tersendiri bagi komunikator karena komunikan dapat memahami pesan yang disampaikan bahkan melakukan tindak lanjut dari pesan tersebut. Akan lebih baik lagi bila komunikasi disampaikan dengan bahasa yang jelas dan mudah dipahami publik sehingga tidak memiliki makna ganda atau tidak terjadi kekaburan makna atas pesan yang disampaikan.

Komunikasi yang dilakukan harus tetap dijalankan secara berkesinambungan sehingga publik tetap mengakui keberadaan suatu organisasi. Sebesar dan setenar apapun suatu organisasi, organisasi tersebut tetap perlu mempublikasikan dirinya secara berkesinambungan agar perhatian publik tidak beralih ke organisasi lain. Publikasi yang gencar sangat diperlukan pada organisasi yang berorientasi profit dengan tingkat persaingan yang tinggi.

Satu hal yang tidak boleh dilupakan bahwa dalam melakukan kegiatan public relations, keberadaan publik yang semakin kritis dan pintar harus menjadi perhatian utama untuk komunikasi di era modern saat ini. Dengan adanya keterbukaan komunikasi yang semakin luas, maka publik akan mengakses informasi dari berbagai penjuru sehingga publik saat ini merupakan publik yang memiliki banyak wawasan.

Oleh karena itu, organisasi harus siap dengan pesan yang kritis dari publiknya. Untuk mendukung jalannya komunikasi, perlu didukung juga dengan berbagai saluran yang dapat mendukung organisasi untuk semakin dikenal publik.

\section{SIMPULAN}

Public relations merupakan kegiatan yang pada dasarnya mengarahkan organisasi untuk memperoleh pengakuan publik.Lebih jauh public relations mengupayakan gerak langkahnya untuk membentuk opini publik yang menguntungkan organisasi sehingga citra positif akan diberikan publik kepada suatu organisasi.

Untuk menunjang kegiatannya, public relations membutuhkan komunikasi agar mampu berinteraksi dengan publiknya dengan komunikasi dua arah. Public relations selalu membuka pintu feed back bagi publiknya sehingga publik bebas mengekspresikan apa yang diinginkan dan apa yang menjadi keluhannya. Respon publik akan ditindaklanjuti sehingga publik akan merasa puas atas apa yang dilakukan organisasi terhadap publiknya. Public relationsjuga senantiasa melakukan evaluasi sehingga pendapat publik dapat terkontrol dengan baik.

Dalam melakukan interaksi dengan 
publik, organisasi harus memperhatikan identitas publik yang saat ini semakin cerdas dan kritis sehingga organisasi tidak boleh menyampaikan informasi yang membuat publik ragu atau tidak percaya atas pesan yang disampaikan. Oleh karena itu, kredibilitas penyampai pesan dari organisasi harus mampu meyakinkan publik sehingga publik menjadi percaya dan menjadi media organisasi dalam mencapai tujuan organisasi.

\section{DAFTAR PUSTAKA}

Cangara, H. Hafied. 2007. Pengantar Ilmu Komunikasi, Jakarta: RajaGrafindo Persada.

Effendy, Onong Uchjana. 2002. Hubungan Masyarakat, Suatu Studi Komunikasi, Bandung: Remaja Rosdakarya.

Hubeis, Musa, dkk. 2012. Komunikasi Profesional, Seperangkat Pengembangan Diri, Bogor, IPB Press.

Mukarom, Zainal dan Muhibudin Wijaya Laksana. 2015. Manajemen Public Relations, Panduan Efektif Pengelolaan Hubungan Masyarakat, Bandung: Pustaka Setia.

Ruslan, Rosady. 1997. Kiat dan Strategi Kampanye Public Relations, Jakarta: RajaGrafindo Persada.

Soemirat, Sholeh dan Elvinaro Ardianto. 2012. Dasar-dasar Public Relations, Bandung: Remaja Rosdakarya.

Suranto, AW. 2005. Komunikasi Perkantoran, Prinsip Komunikasi untuk Meningkatkan Kinerja Perkantoran, Yogyakarta: Media Wacana.

Wiryanto, MA 2002. Pengantar Ilmu Komunikasi, Jakarta: PT Gramedia Widiasarana Indonesia. 
